\title{
Biometric characteristics of fruits and leaves of Cornus officinalis Siebold et Zucc. genotypes in the M.M. Gryshko National Botanical Garden of the NAS of Ukraine
}

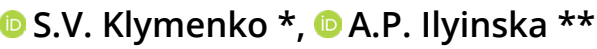 \\ M.M. Gryshko National Botanical Garden, National Academy of Sciences of Ukraine, Timiryazevska str., 1, 01014 Kyiv, Ukraine; \\ * cornusklymenko@gmail.com, ** ilynska@ukr.net
}

Received: 24.01 .2020 | Accepted: 16.05 .2020 | Published: 30.06 .2020

\begin{abstract}
In the context of global climate change, the current strategy of agroeconomics focuses on the introduction of unique plant species and the selection of new commercially important cultivars adapted to the dramatic weather changes. Cornus officinalis (Cornaceae) has Chinese origin, its reintroduction at the M.M. Gryshko National Botanical Garden, National Academy of Sciences of Ukraine started in 1993.

The objectives of this research were: to investigate the biometric parameters of fruits and leaves of C. officinalis genotypes, C. officinalis $\times$ C. mas hybrid 'Etude' and genotype from the grafting C. officinalis on C. mas under cultivation in the M.M. Gryshko National Botanical Garden, National Academy of Sciences of Ukraine, and to determine the degree of adaptation of $C$. officinalis to the climatic conditions of Ukraine (in particular, Right-Bank Forest Steppe) for selection of promising genotypes for further breeding work.

Material and methods. We used: a) 26-year-old maternal plant obtained from a two-year-old seedling in 1993 received from the nursery "Northwoods Wholesale Nursery" Mollala (Oregon, USA), where it was grown as an ornamental plant; b) seedlings of the maternal plant; c) cultivar Etude, which is an artificial hybrid from crossing C. officinalis $\times$ C. mas; and d) genotype obtained from grafting C. officinalis on C. mas. In our experiment, the maternal plant is indicated as G-01, while other plants - as G-02-G-08 genotypes. We determined the biometric parameters of the fruit (length, diameter, and weight), endocarp (length, diameter, and weight), pedicel (length and thickness), leaf blade (length, width, and the number of lateral veins) and petiole (length, width, and thickness). We examined the dynamics of fruit and endocarp formation during the season (genotypes G-01-G-03 and G-05) and compared the biometric characteristics of the fruit of genotypes G-01-G-05 from crops of two years, 2010 and 2018, which were most favorable in weather conditions. We have processed quantitative data in the PAST 2.10 software. The differences between the samples were estimated using the Tukey-Kramer test. The degree of variability was determined by the coefficient of variation. To assess the level of variability, we used the classification of Mamaev (1975).
\end{abstract}

Results. We have found that the largest fruits in 2010 were observed in the genotype G-01 and the smallest - in the genotype G-03. The coefficient of variation of the linear parameters of the fruit and endocarp was in the range 5.7-10.1\%; the level of variability was very low or low. The variability of fruit weight and endocarp was high; the coefficient of variation was from 7.0 up to $28.3 \%$. The amplitude of the linear parameters of the leaf was wide (coefficient of variation was from 9.8 to $31.0 \%$ ). The cultivar Etude differed from other C. officinalis genotypes in size and weight of $(\mathrm{M}=1800 \mathrm{mg}$, $\mathrm{max}=2400 \mathrm{mg})$ and a much wider amplitude of variation in the length (17.9-22.6 vs. 14.3-18.2 mm) of the fruit. The largest leaves were in the genotypes G-08 and G-01, and the smallest - in the genotype G-02. The cultivar Etude did not differ so much by the mean leaf morphometric indices and number of veins, but it demonstrated one of the broadest leaf blades $(51.5 \mathrm{~mm})$. 
Conclusions. The data obtained in this study is important for the commercial use of $C$. officinalis and the cultivar Etude as food and medicinal plant, as well as for breeding in climatic conditions of Ukraine and analysis of hybridization features in the genus Cornus in general.

Keywords: Cornus officinalis, hybrid, introduction, biometrics, fruit, leaf

\section{Introduction}

Modern climate change is related to rising temperatures, increasing carbon dioxide concentrations, the widespread melting of snow and ice, and raising the world's ocean level (Schneider, 2004; Shindell, 2007; Ceccarelli et al., 2010). Droughts have increased in Ukraine over the past 15 years, both in intensity and frequency, that affected yields. Further climate change may result in increased temperature extremes, especially in the southern part of Ukraine (Fileccia et al., 2014). One of the ways of adaptation to adverse climate changes is the minimization of the risk of crop losses by the introduction of new plant species and the selection of new cultivars resistant to sudden weather changes, heat shock and drought (Crossa et al., 2017; Taunk et al., 2017; Ortiz, 2018). In this aspect, Cornus L. species, the introduction, and acclimatization of which have already begun in the M.M. Gryshko National Botanical Garden of the NAS of Ukraine (NBG) are very promising (Klymenko et al., 2017a, b).

The genus Cornus includes nearly 60 species, distributed mainly in the northern boreal and temperate regions, as well as in the tropical and subtropical (rarely) mountains of America, Eurasia, and Africa (Murrell \& Poindexter, 2016). This genus has always attracted the attention of botanists and breeders. The structure of inflorescences (Feng et al., 2011; Zhang et al., 2013), morphology and anatomy of fruits (Morozowska et al., 2013; Woźnicka et al., 2015; Moradi et al., 2019) and leaves (Klymenko \& Klymenko, 2017), general biological features (Weaver, 1976; Reed, 2004; Prevéy, 2020) and reproductive biology (Cornescu \& Cosmulescu, 2017), systematics (Wangerin, 1910; Hutchinson, 1942; Takhtajan, 1987), species composition in different regions of Europe (Poyarkova, 1950, 1951; Klimenko, 2004), Asia (Xiang \& Boufford, 2005) and North America (Ferguson, 1966; Murrell \& Poindexter, 2016), phylogenetic relationships (Murrell,
1993; Xiang et al., 2006; Yue et al., 2018), the evolution of morphological characters (Eyde, 1988), peculiarities of evolution (Manchester, 2010; Atkinson, 2016; Stockey et al., 2016) and biogeography (Xiang et al., 2006; Call et al., 2015) were widely investigated. The family Cornaceae Bercht. et J. Presl, including the genus Cornus, is also the object of molecular studies (Yu et al., 2017; Fu et al., 2017; Li et al., 2020). Much attention has been recently paid to the study of the chemical composition and antioxidant activity (Kryvoruchko \& Kryvoruchko, 2018; Klymenko et al., 2019), pharmacological (Hosseinpour-Jaghdani et al., 2017; Huang et al., 2018) and medicinal application (Dinda et al., 2016; Yue et al., 2018; Czerwińska, \& Melzig, 2018) of Cornus species, as well as their commercial value (Krośniak et al., 2010; Kazimierski et al., 2019). Cornus species contribute to the diversity of wild genotypes and serve as potential for the breeding of the new varieties (Brindza et al., 2007; Cornescu \& Cosmulescu, 2017; Jaćimović \& Božović, 2017; Szot et al., 2019).

The genus Cornus is relatively uniform in flower structure and leaf morphology, but very heterogeneous in the structure of inflorescences and morphology of bracts and fruits (Murrell, 1993; Zhang et al., 2013; Murrell \& Poindexter, 2016). This fact results in the delimitation of four to ten sections and subgenera, which sometimes are considered as separate genera (Wangerin, 1910; Poyarkova, 1951; Takhtajan, 1987).

Cornus s. str. comprises four species: C. chinensis Wangerin (native to Central China), C. sessilis Torr. ex Dur. (naturally growing in the western part of North America (California and Oregon), C. officinalis Siebold et Zucc. (aboriginal to the north of Central and SouthEastern China, where occurs in forested areas at 400 to 1500 (2100) m altitude; also cultivated in Japan and Korea) and C. mas L. (the natural range includes Southern and partly Central Europe to the Balkans, Asia Minor, and the Caucasus). In Ukraine, C. mas grows naturally 
in the Crimea, as well as on the narrow Transnistria strip from the western border of Ivano-Frankivsk to the northern part of the Odesa region. In addition to the Crimean range, C. mas is distributed in mountain forests and hillsides in Transcarpathia. One such locality is in the vicinity of Botar village and covers the area of about 30 hectares. It is one of the largest natural populations of C. mas not only in Ukraine but also in Europe (Fodor, 1974). In some areas of Cherkasy and Kirovograd regions, there are isolated natural locations, and relict 'cornelian cherry hills' have been preserved along the Dnipro River (Kleopov, 1990).

Cornus chinensis and C. sessilis are difficult for cultivation and are almost not applied in selection work (Weaver, 1976). However, C. chinensis is used in Chinese folk medicine in the same way as C. officinalis (Xiang \& Boufford, 2005). C. mas is one of the most studied species of the genus and, at the same time, one of the most valuable fruiting representatives of the Cornaceae family (Klymenko et al., 2017a, b, 2019). Its cultivated habitat covers almost all Europe, partly North America and other regions. C. mas is widely cultivated in private farms in Austria, Italy, France, Poland, Czech Republic, Slovakia, and especially in Bulgaria. It has been used for hundreds of years as a medicinal plant in Bulgaria, and many varieties have already been created there (Klimenko, 2004; Klymenko et al., 2017a, b).

In Ukraine, cornelian cherry trees are common in the private and farm gardens of Zakarpattia, Ternopil, Vinnytsia, Cherkasy, Zaporizhia, Khmelnytskyi, Poltava, and Kyiv Oblasts and Crimea. The northern border of the successful fruiting cornelian cherry passes through Chernihiv - Hlukhiv. In Ukraine, the cultivars of $\mathrm{C}$. mas are widely introduced in horticulture (Klimenko, 2004). In particular, the most significant gene pool of cultivars and forms of this species (30 cultivars and about 100 forms) was collected at the NBG. Hence, the most cornelian cherry assortment in Ukraine consists of cultivars that originated from NBG breeding.

Asian-originated species C. officinalis is not widespread outside the natural range. In Korea, and especially in Japan (locally called sandzaki), medicinal cornel is cultivated for edible fruits and as a medicinal plant (Cao et al., 2016; Li et al., 2012). Since the 1870s, it has also been cultivated, mostly in botanical gardens, in Europe (Czerwińska \& Melzig, 2018) and North America (Ferguson, 1966; Xiang \& Boufford, 2005). It is interesting that in the $\mathrm{UK}, \mathrm{C}$. officinalis is more frequently cultivated as a garden plant than C. mas (Klymenko et al., 2017a).

In China, C. officinalis has been grown and widely used in traditional medicine for thousands of years (Czerwińska \& Melzig, 2018). And now, it is cultivated there as a nationally protected medicinal plant thanks to its medical and commercial importance (Li et al., 2012). In Japan, plantings of seedlings of wild and cultivated genotypes are used to harvest medicinal raw materials. The cultivation of plants beyond their natural growth is of great importance. It is based on the individual variability of these plants. Therefore, valuable forms were selected from nature and transferred to the culture. The diversity of the chosen forms is explained by the fact that the plantations in amateur gardening are mostly represented by seedlingderived material, which is heterozygous. Taking into account that cornelian cherries are cross-pollinated plants, the seeds of the original forms usually do not preserve in such collections.

Pharmacological studies showed that vegetative raw materials of $C$. officinalis have neuroprotective, anti-diabetic, antiinflammatory, antioxidant, and cardiovascular effects. The biochemical composition and medicinal properties of $C$. officinalis fruits have been extensively studied, especially in Japan, Korea (Krośniak et al., 2010; Kryvoruchko \& Kryvoruchko 2018) and China (Cao et al., 2016; Ji et al., 2019). There was almost no breeding work for this species. Only in China explorations on the phenotypic and genetic diversity of local cultivars and wild genotypes are conducting (Li et al., 2012). Before the 1990s, the collection, evaluation, conservation, and use of $\mathrm{C}$. officinalis germplasm had a high scientific priority. The Laboratory of Development of Endangered Chinese Raw Narcotic Resources (North-Western China) has now collected 73 samples of nine germplasm types. Morphology and phytochemistry confirmed the differences among these germplasm types (Li et al., 2012), and, hence, are promising tools for their investigation.

For Ukraine, C. officinalis is a new and 
promising food and medicinal plant. It is cultivated only in the botanical gardens, in particular in the O.V. Fomin Botanical Garden of Taras Shevchenko National University of Kyiv. The introduction of C. officinalis in the NBG is closely related to the establishment of the collection of Cornaceae at the Dendrology Department, considering the possibility of its comprehensive application (i.e., as fruiting, medicinal, ornamental and timber plants). C. officinalis was a part of the first batch of Cornus species, the mass planting of which began in early 1949. Unfortunately, in subsequent years, this collection, including C. officinalis, died due to an incorrectly selected planting place and lack of irrigation (at the early stages it is essential), which caused insufficient winter hardiness and, finally, death of plants. Later, in 1993, C. officinalis was successfully reintroduced at the NBG. Since then, comprehensive and intensive introductory, biological and ecological studies of this species are carrying out at the Department of Acclimatization of Fruit Plants.

The morpho-biological features of C. officinalis and C. mas are similar, with differences in leaves and fruits. The fruits are similar in shape and color. However, fruits of C. officinalis are smaller but remain on the plant for a long time after full ripening. The leaves of C. officinalis are glossy, dark green, rounded, or rounded ovate with elongatedpointed and often twisted apex, wedge-shaped base, and tufts of brown hairs in the corners of the largest lateral veins. In C. mas, leaves are bluish-green, oval, or elliptical with a gradually pointed apex and a rounded or wedge-shaped base and tufts of colorless hairs in the corners of the largest lateral veins.

The NBG is currently breeding this species to use the results of spontaneous intraspecific variation in the selection of the most promising forms. The work is focused on obtaining the interspecific hybrids of C. officinalis $\times$ C. mas that produce large long-maturing fruits. In particular, at the NBG, C. officinalis plants were artificially pollinated with C. mas pollen (a mixture of pollen of 'Lukyanovsky' and 'Olena' cultivars) and thus obtained a cultivar Etude.

For the mass vegetative propagation of cultivars of cornelian cherry, different species of the Cornaceae family were tested as rootstocks. The best compatibility for vegetative propagation has been found in C. mas and C. officinalis. Ideal growth of grafted components of both C. mas on C. officinalis and C. officinalis on C. mas (85-90\%) was observed, which is explained by their close phylogenetic affinity. Other Cornaceae species (C. kousa Bürger ex Miq, C. florida L., C. nuttallii Audubon, Swida spp.) were found incompatible with C. mas and C. officinalis.

At the NBG, C. officinalis plants and cultivar Etude bloom profusely and produce fruits. They are undemanding to cultivation conditions, grow successfully on various soils (from acidic to alkaline), and are characterized by high winter resistance. These plants are also highly decorative (Klymenko et al., 2017a).

The introduction experiment on the acclimatization of $\mathrm{C}$. officinalis in Ukraine continues. Present work aimed: a) to investigate the biometric parameters of fruits and leaves of C. officinalis genotypes, C. officinalis $\times$ C. mas (cv. 'Etude') and genotype from the grafting C. officinalis on C. mas under cultivation in NBG; and b) to determine the degree of adaptation of $C$. officinalis to the local climatic conditions (in particular, RightBank Forest Steppe of Ukraine) and selection of promising genotypes for future breeding work.

\section{Material and methods}

\section{Biological material}

For the study we used: a) 26-year-old maternal plant obtained from a two-year-old seedling received in 1993 from the nursery "Northwoods Wholesale Nursery" Mollala (Oregon, USA), where it was grown as an ornamental plant; b) seedlings of the mother plant; c) cultivar Etude, which is an artificial hybrid from crossing C. officinalis $\times$ C. mas; and d) genotype obtained from grafting C. officinalis on C. mas. In our experiment, the maternal plant is indicated as G-01, while other plants as G-02-G-08 genotypes respectively (Table 1).

\section{Biometric analysis}

The following quantitative traits were used to test selected genotypes: length, diameter, and weight of the fruit and endocarp; length and 
Table 1. The list of investigated genotypes.

\begin{tabular}{|c|c|c|c|}
\hline \multirow{2}{*}{ Genotype } & \multirow{2}{*}{ Origin } & \multicolumn{2}{|c|}{ Dates of measurements } \\
\hline & & fruit & leaf \\
\hline G-01 & $\begin{array}{l}\text { C. officinalis maternal plant obtained in } 1993 \text { from the } \\
\text { Northwoods Wholesale Nursery Mollala nursery }\end{array}$ & $\begin{array}{l}28.09 .2010 \\
21.10 .2010 \\
03.11 .2010 \\
01.11 .2018\end{array}$ & 07.10 .2010 \\
\hline G-02 & $\begin{array}{l}\text { C. officinalis seedling of the maternal plant obtained in } 2002 \text { at } \\
\text { the NBG }\end{array}$ & $\begin{array}{l}21.10 .2010 \\
03.11 .2010 \\
01.11 .2018\end{array}$ & 07.10 .2010 \\
\hline G-03 & $\begin{array}{l}\text { C. officinalis seedling of the maternal plant obtained in } 2002 \text { at } \\
\text { the NBG }\end{array}$ & $\begin{array}{l}21.10 .2010 \\
03.11 .2010 \\
01.11 .2018\end{array}$ & 07.10 .2010 \\
\hline G-04 & $\begin{array}{l}\text { C. officinalis seedling of the maternal plant obtained in } 2002 \text { at } \\
\text { the NBG }\end{array}$ & 01.11 .2018 & not analyzed \\
\hline G-05 & $\begin{array}{l}\text { C. officinalis } \times \text { C. mas hybrid (cv. 'Etude') obtained in } 2000 \text { at the } \\
\text { NBG }\end{array}$ & $\begin{array}{l}28.09 .2010 \\
11.10 .2010 \\
21.10 .2010 \\
03.11 .2010 \\
01.11 .2018\end{array}$ & 07.10 .2010 \\
\hline G-06 & $\begin{array}{l}\text { C. officinalis seedling of the maternal plant obtained in } 2002 \text { at } \\
\text { the NBG }\end{array}$ & not analyzed & 07.10 .2010 \\
\hline G-07 & $\begin{array}{l}\text { C. officinalis seedling of the maternal plant obtained in } 2002 \text { at } \\
\text { the NBG }\end{array}$ & not analyzed & 07.10 .2010 \\
\hline G-08 & $\begin{array}{l}\text { the plant from the grafting C. officinalis on C. mas obtained in } \\
2000 \text { at the NBG }\end{array}$ & not analyzed & 07.10 .2010 \\
\hline
\end{tabular}

width of pedicel; length, width, and a number of lateral veins of the leaf blade; length, width, and thickness of the petiole. We examined the dynamics of fruit and endocarp formation during the season (for genotypes G-01-G-03 and G-05) and compared the biometric characteristics of the fruit of genotypes G-01-G-05 from crops of two years, 2010 and 2018, which were the most favorable in weather-climatic conditions for fruiting plants. The morphometric parameters of the leaf were examined in the same genotypes with the exception of G-04.

\section{Statistical analysis}

We have processed quantitative data using the free data processing software PAST 2.10 (Hammer et al. 2001). We used the main descriptors to characterize all the samples: the arithmetic mean and its error $(\mathrm{M} \pm \mathrm{m})$, the minimum and maximum values (min$\max )$, and the coefficient of variation $(\mathrm{CV}, \%)$. The differences between the samples were estimated using the Tukey-Kramer test. The degree of variability was determined by the coefficient of variation. To assess the level of variability, we used the classification of Mamaev (1975).

\section{Results and discussion}

\section{Fruit biometric parameters}

Genotypes of C. officinalis (Table 2; Fig. 1). In 2010, the average length of fruits varied from 13.8 to $16.5 \mathrm{~mm}$, and diameter from 7.7 to $10.5 \mathrm{~mm}$. The average length of endocarp was $12.2-13.5 \mathrm{~mm}$, and average diameter 4.6-5.4 $\mathrm{mm}$. The average length of pedicels was $7.7-10.2 \mathrm{~mm}$, and average width - 0.2$0.6 \mathrm{~mm}$. During October 2010, in G-01-G-03 genotypes, the mean value of fruit size and endocarp increased by increasing the number of large fruits. At the end of the autumn season of 2010 (03.11.2010), the largest fruits were in the maternal plant (genotype G-01), and significantly smallest - in the genotype G-03. Under favorable weather conditions, fruits of G-01, G-02, G-03, and G-04 genotypes were even larger, and the amplitude of traits shifted toward higher values (Table 2). The linear 
Table 2. Biometric parameters of the fruits of investigated Cornus officinalis genotypes.

\begin{tabular}{|c|c|c|c|c|c|c|c|c|}
\hline \multirow[b]{2}{*}{ Parameters } & \multicolumn{3}{|c|}{ Fruit } & \multicolumn{3}{|c|}{ Endocarp } & \multicolumn{2}{|c|}{ Pedicel } \\
\hline & $\begin{array}{l}\text { length, } \\
\mathrm{mm}\end{array}$ & $\begin{array}{l}\text { diameter, } \\
\mathrm{mm}\end{array}$ & $\begin{array}{l}\text { weight, } \\
\text { mg }\end{array}$ & $\begin{array}{l}\text { length, } \\
\mathrm{mm}\end{array}$ & $\begin{array}{l}\text { diameter, } \\
\mathrm{mm}\end{array}$ & $\begin{array}{l}\text { weight, } \\
\text { mg }\end{array}$ & $\begin{array}{l}\text { length, } \\
\mathrm{mm}\end{array}$ & $\begin{array}{l}\text { width, } \\
\text { mm }\end{array}$ \\
\hline \multicolumn{9}{|c|}{ Cornus officinalis maternal plant (G-01) } \\
\hline \multicolumn{9}{|l|}{ 28.09.2010 } \\
\hline $\mathrm{M} \pm \mathrm{m}$ & $15.9 \pm 0.13^{b}$ & $9.2 \pm 0.09^{\mathrm{b}}$ & $900 \pm 20^{c}$ & $13.3 \pm 0.08^{b}$ & $4.7 \pm 0.04^{\mathrm{a}}$ & $200 \pm 2^{\mathrm{a}}$ & $10.3 \pm 0.22^{b}$ & $0.5 \pm 0.008^{a}$ \\
\hline $\min -\max$ & $14.6-17.5$ & $7.4-10.2$ & $600-1100$ & $12.2-15.0$ & $4.1-6.0$ & $200-300$ & $6.7-13.1$ & $0.3-0.6$ \\
\hline $\mathrm{CV}, \%$ & 4.2 & 5.9 & 11.9 & 4.5 & 6.2 & 7.0 & 15.0 & 13.2 \\
\hline \multicolumn{9}{|l|}{21.10 .2010} \\
\hline $\mathrm{M} \pm \mathrm{m}$ & $15.7 \pm 0.09^{b}$ & $9.3 \pm 0.07^{\mathrm{b}}$ & $1000 \pm 20^{\mathrm{b}}$ & $12.7 \pm 0.12^{\mathrm{ab}}$ & $4.6 \pm 0.04^{\mathrm{a}}$ & $200 \pm 8^{b}$ & $11.1 \pm 0.21^{\mathrm{a}}$ & $0.3 \pm 0.007^{\mathrm{b}}$ \\
\hline $\min -\max$ & $14.0-17.1$ & $8.3-0.4$ & $700-1200$ & $10.8-14.2$ & $4.1-5.7$ & $100-300$ & $8.3-14.6$ & $0.2-0.4$ \\
\hline $\mathrm{CV}, \%$ & 4.3 & 5.4 & 12.2 & 6.5 & 6.8 & 27.9 & 13.7 & 17.1 \\
\hline \multicolumn{9}{|l|}{ 03.11.2010 } \\
\hline $\mathrm{M} \pm \mathrm{m}$ & $15.8 \pm 0.12^{\mathrm{b}}$ & $8.9 \pm 0.10^{\mathrm{ab}}$ & $1000 \pm 20^{\mathrm{b}}$ & $13.5 \pm 0.10^{\mathrm{b}}$ & $4.6 \pm 0.03^{a}$ & $200 \pm 7^{a}$ & $11.6 \pm 0.17^{\mathrm{a}}$ & $0.3 \pm 0.100^{\mathrm{ab}}$ \\
\hline $\min -\max$ & $14.0-17.8$ & $7.5-11.7$ & $700-1200$ & $11.7-15.5$ & $4.0-5.2$ & $200-400$ & $8.3-14.5$ & $0.1-0.4$ \\
\hline $\mathrm{CV}, \%$ & 5.3 & 7.1 & 11.8 & 5.1 & 5.1 & 21.8 & 11.1 & 22.8 \\
\hline \multicolumn{9}{|l|}{ 01.11.2018 } \\
\hline $\mathrm{M} \pm \mathrm{m}$ & $16.5 \pm 0.22^{\mathrm{a}}$ & $10.1 \pm 0.22^{\mathrm{a}}$ & $1200 \pm 20^{\mathrm{a}}$ & n. a. & n. a. & n. a. & n. a. & n. a. \\
\hline $\min -\max$ & $8.1-18.5$ & $9.1-12.1$ & $1000-1700$ & n. a. & n. a. & n. a. & n. a. & n. a. \\
\hline $\mathrm{CV}, \%$ & 9.4 & 5.7 & 13.8 & n. a. & n. a. & n. a. & n. a. & n. a. \\
\hline
\end{tabular}

seedlings of the maternal plant (G-02)

\begin{tabular}{|c|c|c|c|c|c|c|c|c|}
\hline \multicolumn{9}{|l|}{11.10 .2010} \\
\hline $\mathrm{M} \pm \mathrm{m}$ & $15.5 \pm 0.12^{\mathrm{ab}}$ & $9.6 \pm 0.08^{b}$ & $1000 \pm 6^{\mathrm{ab}}$ & $12.6 \pm 0.09^{b}$ & $4.5 \pm 0.04^{\mathrm{b}}$ & $200 \pm 6^{a}$ & $10.0 \pm 0.25^{b}$ & $0.4 \pm 0.008^{\mathrm{ab}}$ \\
\hline $\min -\max$ & $13-17.5$ & $8.5-10.9$ & $700-1300$ & $10.6-14.1$ & $4.0-5.6$ & $100-120$ & $4.5-13.3$ & $0.3-0.6$ \\
\hline $\mathrm{CV}, \%$ & 5.5 & 6.1 & 14.0 & 5.2 & 6.3 & 22.4 & 18.0 & 13.7 \\
\hline \multicolumn{9}{|l|}{ 21.10.2010 } \\
\hline $\mathrm{M} \pm \mathrm{m}$ & $13.8 \pm 0.13^{c}$ & $7.7 \pm 0.11^{\mathrm{c}}$ & $600 \pm 19^{c}$ & $12.3 \pm 0.23^{\mathrm{ab}}$ & & $200 \pm 7^{a}$ & $9.7 \pm 0.19^{a b}$ & $0.2 \pm 0.010^{\mathrm{ab}}$ \\
\hline $\min -\max$ & $12.5-15.3$ & $5.9-8.4$ & $400-800$ & $10.3-14.4$ & & $100-200$ & $7.6-11.9$ & $0.2-0.4$ \\
\hline $\mathrm{CV}, \%$ & 4.8 & 7.4 & 15.4 & 9.2 & & 20.3 & 9.8 & 21.0 \\
\hline \multicolumn{9}{|l|}{03.11 .2010} \\
\hline $\mathrm{M} \pm \mathrm{m}$ & $14.5 \pm 0.15^{\mathrm{c}}$ & $8.4 \pm 0.16^{\mathrm{ab}}$ & $700 \pm 20^{\text {cd }}$ & $12.2 \pm 0.10^{\mathrm{ab}}$ & $4.5 \pm 0.04^{\mathrm{ab}}$ & $200 \pm 4^{b}$ & $9.1 \pm 0.22^{\mathrm{ab}}$ & $0.3 \pm 0.020^{\mathrm{a}}$ \\
\hline $\min -\max$ & $13.5-16.9$ & $7.6-11.5$ & $500-1100$ & $11.6-13.7$ & $4.1-4.9$ & $100-200$ & $6.1-10.6$ & $0.2-0.3$ \\
\hline $\mathrm{CV}, \%$ & 5.1 & 9.5 & 16.1 & 4.3 & 4.1 & 10.2 & 12.0 & 19.6 \\
\hline \multicolumn{9}{|l|}{01.11 .2018} \\
\hline $\mathrm{M} \pm \mathrm{m}$ & $16.2 \pm 0.10^{\mathrm{ab}}$ & $9.9 \pm 0.08^{b}$ & $1200 \pm 10^{\mathrm{b}}$ & n. a. & n. a. & n. a. & n. a. & n. a. \\
\hline $\min -\max$ & $14.8-17.4$ & $8.4-10.9$ & $1000-1500$ & n. a. & n. a. & n. a. & n. a. & n. a. \\
\hline $\mathrm{CV}, \%$ & 4.4 & 5.7 & 8.4 & n. a. & n. a. & n. a. & n. a. & n. a. \\
\hline \multicolumn{9}{|c|}{ seedlings of the maternal plant $(\mathrm{G}-03)$} \\
\hline \multicolumn{9}{|c|}{21.10 .2010} \\
\hline $\mathrm{M} \pm \mathrm{m}$ & $15.3 \pm 0.22^{\mathrm{ab}}$ & $10.5 \pm 0.14^{b}$ & $1300 \pm 40^{\mathrm{b}}$ & $12.3 \pm 0.14^{\mathrm{a}}$ & $5.4 \pm 0.06^{\mathrm{a}}$ & $200 \pm 8^{b}$ & $13.0 \pm 0.34^{\mathrm{a}}$ & $0.5 \pm 0.016^{b}$ \\
\hline $\min -\max$ & $11.6-17.3$ & $9.1-11.7$ & $900-1800$ & $10.5-13.9$ & $4.5-5.8$ & $200-300$ & $10.1-16.8$ & $0.4-0.7$ \\
\hline $\mathrm{CV}, \%$ & 7.2 & 6.5 & 16.1 & 5.8 & 5.6 & 19.5 & 13.1 & 16.6 \\
\hline
\end{tabular}

Note: means followed by different letters are different at $\mathrm{P}<0.05$; each value represents the mean of three independent experiments ( \pm SD); min - minimum values; max - maximum values; CV, \% - coefficient of variation; n. a. - not analyzed. 
Table 2. Continued.

\begin{tabular}{|c|c|c|c|c|c|c|c|c|}
\hline \multirow[b]{2}{*}{ Parameters } & \multicolumn{3}{|c|}{ Fruit } & \multicolumn{3}{|c|}{ Endocarp } & \multicolumn{2}{|c|}{ Pedicel } \\
\hline & $\begin{array}{l}\text { length, } \\
\mathrm{mm}\end{array}$ & $\begin{array}{l}\text { diameter, } \\
\mathrm{mm}\end{array}$ & $\begin{array}{l}\text { weight, } \\
\text { mg }\end{array}$ & $\begin{array}{l}\text { length, } \\
\mathrm{mm}\end{array}$ & $\begin{array}{l}\text { diameter, } \\
\mathrm{mm}\end{array}$ & $\begin{array}{l}\text { weight, } \\
\text { mg }\end{array}$ & $\begin{array}{l}\text { length, } \\
\mathrm{mm}\end{array}$ & $\begin{array}{l}\text { width, } \\
\text { mm }\end{array}$ \\
\hline \multicolumn{9}{|c|}{ seedlings of the maternal plant (G-03) } \\
\hline \multicolumn{9}{|l|}{03.11 .2010} \\
\hline $\mathrm{M} \pm \mathrm{m}$ & $15.1 \pm 0.17^{c}$ & $10.2 \pm 0.20^{\mathrm{b}}$ & $1200 \pm 50^{\mathrm{ab}}$ & $12.2 \pm 0.15^{\mathrm{a}}$ & $5.3 \pm 0.06^{\mathrm{b}}$ & $300 \pm 10^{\mathrm{a}}$ & $12.7 \pm 0.17^{\mathrm{ab}}$ & $0.6 \pm 0.020^{\mathrm{a}}$ \\
\hline $\min -\max$ & $13.9-17.2$ & 7.5-13.3 & $600-1600$ & $11.1-14.2$ & $4.4-5.8$ & $200-300$ & $10.6-14.1$ & $0.4-0.7$ \\
\hline $\mathrm{CV}, \%$ & 5.6 & 10.1 & 20.4 & 6.1 & 6.0 & 19.2 & 6.9 & 16.7 \\
\hline \multicolumn{9}{|l|}{01.11 .2018} \\
\hline $\mathrm{M} \pm \mathrm{m}$ & $16.3 \pm 0.09^{\mathrm{a}}$ & $9.9 \pm 0.07^{\mathrm{ab}}$ & $1200 \pm 20^{\mathrm{a}}$ & n. a. & n. a. & n. a. & n. a. & n. a. \\
\hline $\min -\max$ & $14.7-17.7$ & $8.8-10.8$ & $1000-1500$ & n. a. & n. a. & n. a. & n. a. & n. a. \\
\hline $\mathrm{CV}, \%$ & 4.1 & 4.7 & 9.4 & n. a. & n. a. & n. a. & n. a. & n. a. \\
\hline \multicolumn{9}{|l|}{03.11 .2010} \\
\hline $\mathrm{M} \pm \mathrm{m}$ & $16.7 \pm 0.19^{\mathrm{a}}$ & $10.1 \pm 0.09^{\mathrm{a}}$ & $1200 \pm 30^{\mathrm{ab}}$ & $13.8 \pm 0.15^{\mathrm{a}}$ & $5.2 \pm 0.05^{\mathrm{a}}$ & $300 \pm 4^{\mathrm{a}}$ & $9.3 \pm 0.17^{\mathrm{a}}$ & $0.2 \pm 0.010^{b}$ \\
\hline $\min -\max$ & $14.7-18.1$ & $8.7-10.7$ & $1000-1600$ & $12.5-15.0$ & $4.7-5.6$ & $300-400$ & $7.2-11.0$ & $0.2-0.3$ \\
\hline $\mathrm{CV}, \%$ & 5.7 & 4.6 & 12.3 & 5.5 & 4.3 & 6.6 & 9.1 & 20.3 \\
\hline \multicolumn{9}{|c|}{ seedlings of the maternal plant (G-04) } \\
\hline \multicolumn{9}{|c|}{01.11 .2018} \\
\hline $\mathrm{M} \pm \mathrm{m}$ & $16.7 \pm 0.11^{\mathrm{a}}$ & $10.2 \pm 0.06^{\mathrm{a}}$ & $1200 \pm 20^{\mathrm{a}}$ & n. a. & n. a. & n. a. & n. a. & n. a. \\
\hline $\min -\max$ & $14.9-18.9$ & $9.1-11.3$ & $1100-1600$ & n. a. & n. a. & n. a. & n. a. & n. a. \\
\hline $\mathrm{CV}, \%$ & 4.5 & 4.4 & 8.9 & n. a. & n. a. & n. a. & n. a. & n. a. \\
\hline \multicolumn{9}{|c|}{ cultivar Etude (G-05) } \\
\hline \multicolumn{9}{|c|}{28.09 .2010} \\
\hline $\mathrm{M} \pm \mathrm{m}$ & $15.6 \pm 014^{\mathrm{ab}}$ & $11.2 \pm 0.11^{\mathrm{a}}$ & $1300 \pm 30^{\mathrm{b}}$ & $12.4 \pm 0.12^{\mathrm{a}}$ & $5.4 \pm 0.06^{\mathrm{a}}$ & $200 \pm 7^{\mathrm{b}}$ & $12.4 \pm 0.38^{b}$ & $0.6 \pm 0.01^{\mathrm{a}}$ \\
\hline $\min -\max$ & $14.4-17.0$ & $10.0-12.3$ & $1100-1600$ & $11.0-13.5$ & $4.9-6.0$ & $200-300$ & $8.7-15.8$ & $0.4-0.7$ \\
\hline $\mathrm{CV}, \%$ & 4.4 & 4.8 & 10.7 & 4.9 & 5.6 & 17.3 & 15.1 & 11.4 \\
\hline \multicolumn{9}{|l|}{11.10 .2010} \\
\hline $\mathrm{M} \pm \mathrm{m}$ & $16.0 \pm 0.15^{\mathrm{b}}$ & $11.3 \pm 0.11^{a}$ & $1400 \pm 30^{\mathrm{b}}$ & $12.1 \pm 0.10^{\mathrm{a}}$ & $5.3 \pm 0.05^{\mathrm{a}}$ & $200 \pm 6^{c}$ & $14.0 \pm 0.59^{\mathrm{a}}$ & $0.6 \pm 0.01^{\mathrm{a}}$ \\
\hline $\min -\max$ & $14.3-18.2$ & $10.3-12.5$ & $1000-1700$ & $11.1-13.1$ & $4.4-5.8$ & $200-300$ & $11.5-32.0$ & $0.5-0.8$ \\
\hline $\mathrm{CV}, \%$ & 5.3 & 5.1 & 12.3 & 4.8 & 5.3 & 16.7 & 24.4 & 12.5 \\
\hline \multicolumn{9}{|l|}{21.10 .2010} \\
\hline $\mathrm{M} \pm \mathrm{m}$ & $16.8 \pm 0.15^{\mathrm{a}}$ & $10.0 \pm 0.09^{\mathrm{a}}$ & $1200 \pm 20^{a}$ & $13.7 \pm 0.20^{\mathrm{a}}$ & $5.0 \pm 0.07^{b}$ & $200 \pm 10^{\mathrm{b}}$ & $9.0 \pm 0.20^{\mathrm{b}}$ & $0.3 \pm 0.020^{\mathrm{a}}$ \\
\hline $\min -\max$ & $15.4-18.2$ & $9.0-11.2$ & $1000-1500$ & $10.8-15.1$ & $4.5-5.7$ & $100-200$ & $7.0-11.0$ & $0.1-0.4$ \\
\hline $\mathrm{CV}, \%$ & 4.5 & 4.5 & 10.3 & 7.3 & 6.9 & 28.3 & 11.2 & 28.6 \\
\hline \multicolumn{9}{|l|}{ 03.11.2010 } \\
\hline $\mathrm{M} \pm \mathrm{m}$ & $16.7 \pm 0.19^{a}$ & $10.1 \pm 0.09^{a}$ & $1200 \pm 30^{\mathrm{ab}}$ & $13.8 \pm 0.15^{\mathrm{a}}$ & $5.2 \pm 0.05^{\mathrm{a}}$ & $300 \pm 4^{\mathrm{a}}$ & $9.3 \pm 0.17^{\mathrm{a}}$ & $0.2 \pm 0.010^{b}$ \\
\hline $\min -\max$ & $14.7-18.1$ & $8.7-10.7$ & $1000-1600$ & $12.5-15.0$ & $4.7-5.6$ & $300-400$ & $7.2-11.0$ & $0.2-0.3$ \\
\hline $\mathrm{CV}, \%$ & 5.7 & 4.6 & 12.3 & 5.5 & 4.3 & 6.6 & 9.1 & 20.3 \\
\hline \multicolumn{9}{|l|}{01.11 .2018} \\
\hline $\mathrm{M} \pm \mathrm{m}$ & $19.9 \pm 0.15^{\mathrm{a}}$ & $11.1 \pm 0.08^{\mathrm{a}}$ & $1800 \pm 30^{\mathrm{a}}$ & n. a. & n. a. & n. a. & n. a. & n. a. \\
\hline $\min -\max$ & $17.9-22.6$ & $9.4-12.4$ & $1500-2400$ & n. a. & n. a. & n. a. & n. a. & n. a. \\
\hline $\mathrm{CV}, \%$ & 5.4 & 5.1 & 12.8 & n. a. & n. a. & n. a. & n. a. & n. a. \\
\hline
\end{tabular}

Note: means followed by different letters are different at $P<0.05$; each value represents the mean of three independent experiments ( \pm SD); min - minimum values; max - maximum values; CV, \% - coefficient of variation; n. a. - not analyzed. 

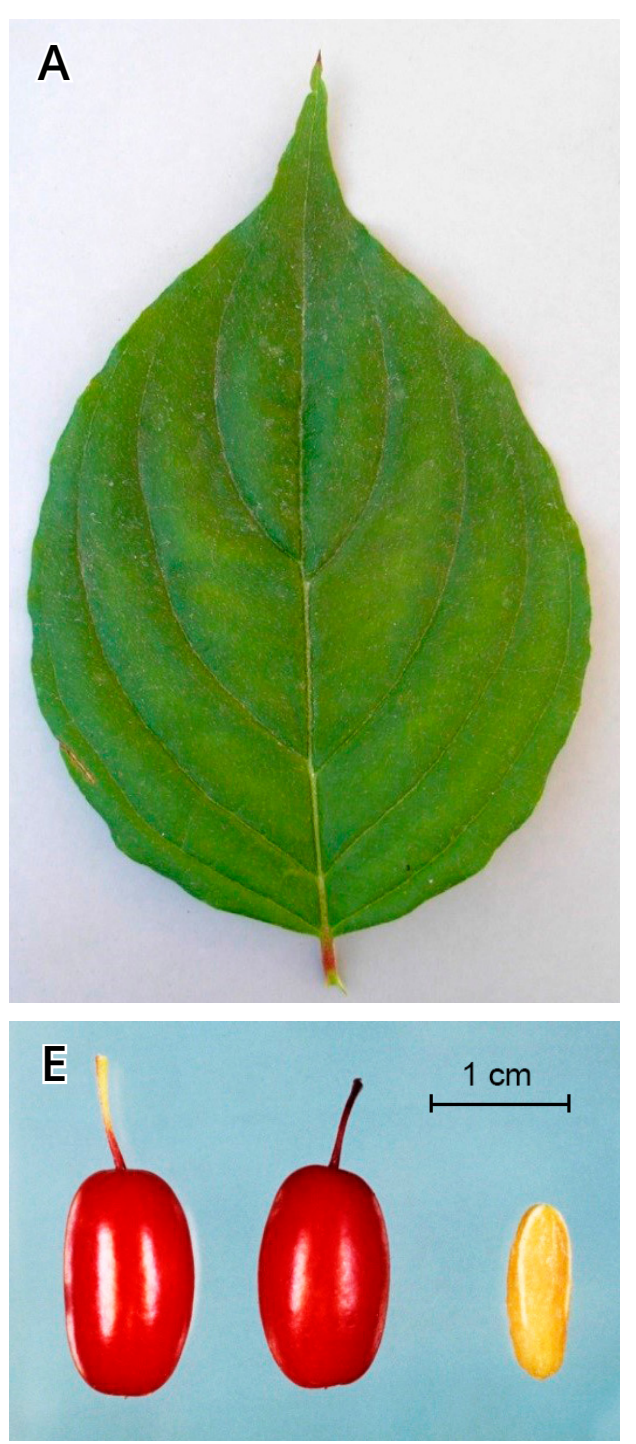
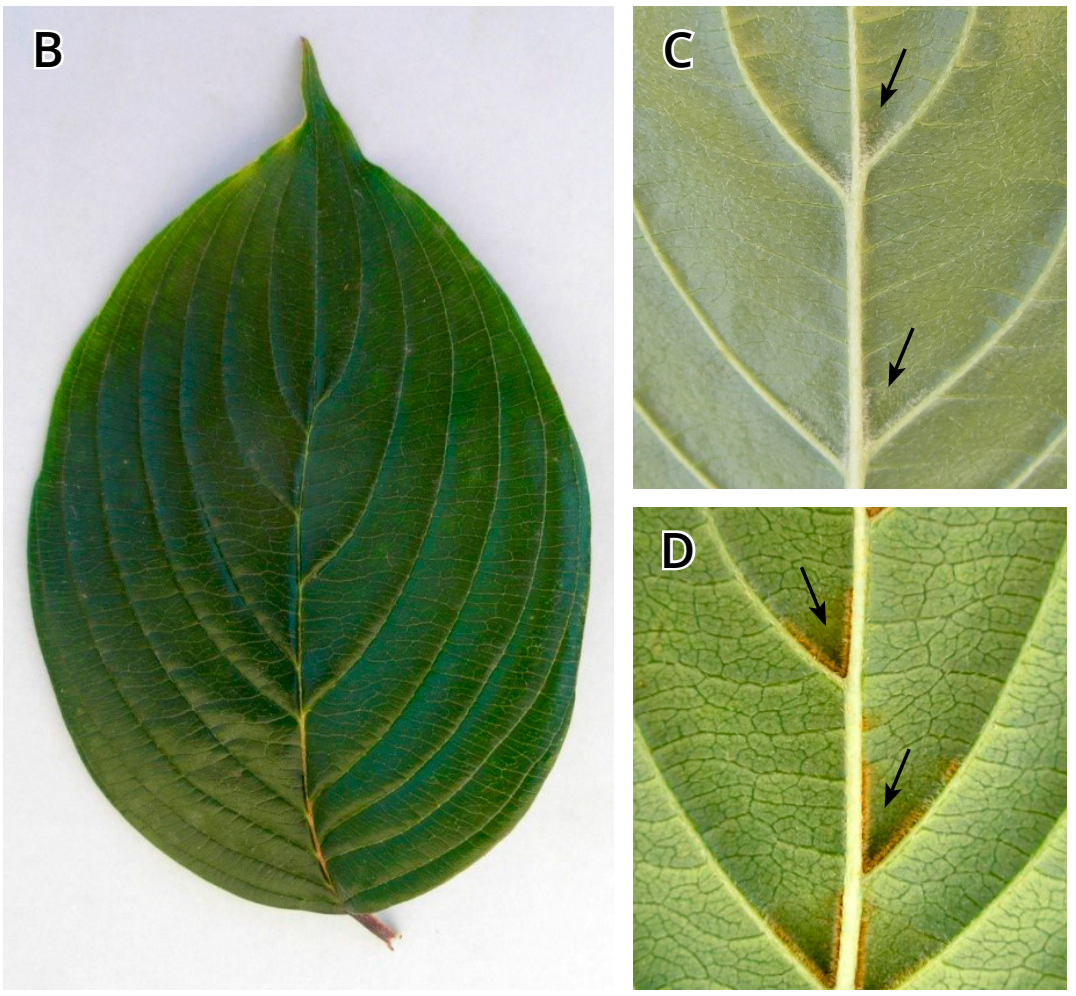

Figure 1. The leaves of Cornus mas (A, C) and C. officinalis (B, D), and the fruits and endocarp of cultivar Etude (E). Arrows on $C$ - colorless hairs on the abaxial surface of C. mas leaf. Arrows on $D$ - brown hairs on the abaxial surface of $C$. officinalis leaf. dimensions of the fruit and endocarp were stable. Their coefficient of variation (CV) in most genotypes did not exceed $7 \%$, which corresponds to a very low level of variability. Rarely $\mathrm{CV}$ varied from $7.1 \%$ to $10.1 \%$. The average values of fruit weight and endocarp of the C. officinalis genotypes were 600-1000 and 200-300 mg, respectively. The amplitude of variation in fruit weight in 2010 was $400-1800 \mathrm{mg}$, and in 2018 it shifted toward larger values, but the magnitude of variation was smaller, 1000-1700 mg. Endocarp weight varied within 100-400 mg. The lowest weight, $200 \mathrm{mg}$, was fixed for the genotype G-02. In 2010 (03.11.10), CV for the fruit weight was $11.8-20.1 \%$ (mean variability), and in 2018 (01.11.18), it decreased significantly to $8.4-9.4 \%$ (low variability). The smallest variation was observed in fruit weight, while endocarp weight was characterized by a high level of variability with a CV reaching 7.0-27.9\%.
The cultivar Etude, within average values of the size and weight of its fruits, was almost indistinguishable from maternal plant and seedlings of C. officinalis (Table 2). However, the fruits of 'Etude' in 2018 were much larger (length reached $19.9 \mathrm{~mm}$, and diameter $11.1 \mathrm{~mm}$ ) than those of the maternal plant and seedlings. The cultivar Etude significantly differed by increased variation in fetal length (17.9-22.6 vs. $14.3-18.2 \mathrm{~mm})$, but was almost stable by fruit diameter (Table 2). The mean weight of the fruit was $1800 \mathrm{mg}$; the minimum and maximum values shifted toward higher values. The level of variability in fruit size was very low (the highest $\mathrm{CV}=5.75 \%$ ). The maximum value of the coefficient of variation of fruit mass in 2010 was $12.3 \%$, in 2018 $12.8 \%$, hence, the level of variability was intermediate. Statistical indicators, including the coefficient of variation, size, and weight of the endocarp, were similar to those of the C. officinalis genotypes. The mean length of the 
pedicels in the cultivar Etude varied from 12.4 to $14.0 \mathrm{~mm}$, while in genotypes of C. officinalis - from 9.0 to $11.6 \mathrm{~mm}$. The pedicels of 'Etude' were slightly thicker.

\section{Biometric parameters of leaves}

Genotypes of C. officinalis (Table 3, Fig. 1). The largest leaf blades had the genotypes G-08 and G-01, and the smallest - the genotype G-02. Genotype G-02 had the smallest span of variation in linear dimensions of leaf length and width, 25.3 and $19.7 \mathrm{~mm}$, respectively. Corresponding leaf indices of other C. officinalis genotypes varied within 38.6-49.9 and 26.1-43.1 $\mathrm{mm}$, respectively. The width of the leaf varied more than the length (ranges were 7.2-13.5, and 9.8-18.9 mm, respectively). The mean values of the number of veins were 12.9-14.0 pieces per one leaf, and the min-max values in the studied genotypes were 10-18 pieces. The longest petioles had the leaves of genotype $\mathrm{G}-08$, and the shortest - the leaves of genotype G-02. The level of variation in length was low or intermediate. The coefficient of variation was in the range of $10.3-18.1 \%$. Comparing to the length, the width and thickness of the petiole were more variable, and $\mathrm{CV}$ reached 26.7 and $31.0 \%$, respectively.

Cultivar Etude (Table 3, Fig. 1). The mean, minimum and maximum values and $\mathrm{CV}$ of leaf blade size and petiole did not differ significantly from respective values of C. officinalis genotypes. However, the variation of the width was much larger (with registered $51.5 \mathrm{~mm}$ ), whereas G-01 has only $35.4 \mathrm{~mm}$, and G-07 - only $43.1 \mathrm{~mm}$. The number of veins on the leaf blade of 'Etude' also did not go beyond the amplitude of variation designated for other genotypes. Leaves of C. officinalis and cultivar Etude were found relatively more variable in size, with a low or intermediate level of variation. The leaves of genotype G-08 had the highest length and width and low CV. The genotype G-05 was characterized by medium-sized leaf blades and petioles with low or medium variability, compared to other $\mathrm{C}$. officinalis genotypes.

As a result of the study, the biometric parameters of the fruits, endocarp, and pedicel were established in four genotypes of $C$. officinalis and the cultivar Etude, and leaf blade and petiole - in six genotypes of C. officinalis and the cultivar Etude (Tables $2 \& 3)$.

It is known that for the selection of promising cultivars of fruiting plants, a complex of indicators is applying. In particular, fruit parameters play a crucial role in the selection process. However, leaves, which in the process of photosynthesis, ensure the existence of the plant and accumulation of nutrients in the fruits, are also important. Quantitative traits are especially convenient to control the condition of plants at all stages of introduction and breeding - from initial testing to variety testing, naturalization, and 'complete' acclimatization.

At the NBG, investigations of biometric characteristics of fruits and leaves of nontraditional species of fruiting, medicinal, ornamental, and other commercially important plants are conducting. These investigations are mostly aimed at the evaluation of prospective ways of cultivation of the new plant varieties in conditions of temperate continental climate of the Right-Bank Forest Steppe (Klymenko et al., 2017a, b, c; Rakhmetov, 2018). In particular, statistical indicators of variability have been an integral part of bioecological research of C. mas and its numerous cultivars and forms, including those created at the NBG (Klimenko, 2004; Klymenko et al., 2019). Morphometric characteristics of the fruit were examined in different genotypes of Ziziphus jujuba Mill. (Grygorieva et al., 2014), Elaeagnus multiflora Thunb. (Grygorieva et al., 2018a), Mespilus germanica L. (Grygorieva et al., 2018b), Diospyros virginiana L. (Grygorieva et al., 2017), Cydonia oblonga Mill. (Monka et al., 2014), as well as in Persica Mill. taxa (Holubkova, 2017).

The obtained biometric data showed that the fruits of the studied C. officinalis genotypes and the cultivar Etude have no notable variability. In most cases, the coefficient of variation corresponded to a very low or low level of variation (Mamaev, 1975). The most variable sign was endocarp weight (Table 3). Hence, we attribute endocarp weight to the category of selectively important traits required for the selection of new forms of C. officinalis. Genotypes of C. officinalis and cultivar Etude have responded favorably to weather and climate conditions in 2018. According to the open archive of meteorological station No. 33345 (Igor Sikorsky Kyiv International 
Table 3. Biometric parameters of the leaves of investigated Cornus officinalis genotypes and cultivar Etude.

\begin{tabular}{|c|c|c|c|c|c|c|}
\hline \multirow[b]{2}{*}{ Parameters } & \multicolumn{3}{|c|}{ Leaf blade } & \multicolumn{3}{|c|}{ Petiole } \\
\hline & $\begin{array}{l}\text { length, } \\
\mathrm{mm}\end{array}$ & $\begin{array}{l}\text { width, } \\
\mathrm{mm}\end{array}$ & $\begin{array}{l}\text { number of } \\
\text { lateral veins }\end{array}$ & $\begin{array}{l}\text { length, } \\
\mathrm{mm}\end{array}$ & $\begin{array}{l}\text { width, } \\
\text { mm }\end{array}$ & $\begin{array}{l}\text { thickness, } \\
\mathrm{mm}\end{array}$ \\
\hline \multicolumn{7}{|c|}{ Cornus officinalis maternal plant (G-01) } \\
\hline $\mathrm{M} \pm \mathrm{m}$ & $112.8 \pm 1.62^{\mathrm{a}}$ & $68.6 \pm 1.01^{\mathrm{b}}$ & $13.9 \pm 0.28^{\mathrm{a}}$ & $11.4 \pm 0.30^{\mathrm{a}}$ & $1.5 \pm 0.06^{c}$ & $1.3 \pm 0.06^{\mathrm{b}}$ \\
\hline $\min -\max$ & $89.0-132.9$ & $49.3-84.7$ & $11-17$ & $7.0-17.2$ & $0.9-2.2$ & $0.7-2.0$ \\
\hline $\mathrm{CV}, \%$ & 10.1 & 10.4 & 14.5 & 18.3 & 26.7 & 31.0 \\
\hline \multicolumn{7}{|c|}{ seedling of the maternal plant (G-02) } \\
\hline $\mathrm{M} \pm \mathrm{m}$ & $85.0 \pm 13.7^{\mathrm{ab}}$ & $46.7 \pm 1.21^{\mathrm{ab}}$ & $13.4 \pm 0.18^{\mathrm{ab}}$ & $10.1 \pm 0.15^{b}$ & $1.6 \pm 0.04^{\mathrm{b}}$ & $1.4 \pm 0.04^{\mathrm{b}}$ \\
\hline $\min -\max$ & $69.6-108.2$ & $33.6-76.7$ & $10-16$ & $7.9-12.2$ & $1.1-2.2$ & $1.0-2.0$ \\
\hline $\mathrm{CV}, \%$ & 11.4 & 18.3 & 9.3 & 10.3 & 17.5 & 17.4 \\
\hline \multicolumn{7}{|c|}{ seedling of the maternal plant (G-03) } \\
\hline $\mathrm{M} \pm \mathrm{m}$ & $96.0 \pm 1.36^{\mathrm{b}}$ & $54.4 \pm 0.84^{\mathrm{ab}}$ & $12.9 \pm 0.25^{\mathrm{c}}$ & $10.1 \pm 0.22^{\mathrm{b}}$ & $1.6 \pm 0.22^{\mathrm{b}}$ & $1.4 \pm 0.03^{\mathrm{b}}$ \\
\hline $\min -\max$ & $73.5-118.2$ & $45.1-71.2$ & $10-18$ & $7.6-14.2$ & $1.2-2.0$ & $1.0-2.0$ \\
\hline $\mathrm{CV}, \%$ & 10.0 & 10.9 & 14.0 & 15.5 & 11.3 & 13.9 \\
\hline \multicolumn{7}{|c|}{ cultivar Etude (G-05) } \\
\hline $\mathrm{M} \pm \mathrm{m}$ & $98.1 \pm 1.28^{b}$ & $57.4 \pm 1.26^{\mathrm{b}}$ & $14.3 \pm 0.22^{\mathrm{a}}$ & $9.6 \pm 0.12^{\mathrm{ab}}$ & $1.7 \pm 0.03^{b}$ & $1.5 \pm 0.03^{\mathrm{a}}$ \\
\hline $\min -\max$ & $81.2-116.4$ & $43.8-95.3$ & $11-18$ & $7.8-12.4$ & $1.2-2.1$ & $1.1-1.9$ \\
\hline $\mathrm{CV}, \%$ & 9.3 & 15.5 & 11.0 & 8.9 & 13.5 & 12.6 \\
\hline \multicolumn{7}{|c|}{ seedling of the maternal plant (G-06) } \\
\hline $\mathrm{M} \pm \mathrm{m}$ & $81.6 \pm 1.56^{\mathrm{ab}}$ & $45.8 \pm 1.15^{\mathrm{ab}}$ & $13.9 \pm 0.16^{\mathrm{a}}$ & $9.4 \pm 0.17^{\mathrm{ab}}$ & $1.4 \pm 0.03^{\mathrm{c}}$ & $1.1 \pm 0.03^{\mathrm{ab}}$ \\
\hline $\min -\max$ & $53.8-103.7$ & $23.0-61.1$ & $12-17$ & $7.1-12.8$ & $0.9-1.9$ & $0.8-2.0$ \\
\hline $\mathrm{CV}, \%$ & 13.5 & 17.8 & 8.3 & 13.0 & 16.7 & 19.6 \\
\hline \multicolumn{7}{|c|}{ seedling of the maternal plant (G-07) } \\
\hline $\mathrm{M} \pm \mathrm{m}$ & $117.1 \pm 1.22^{\mathrm{a}}$ & $75.2 \pm 1.3^{\mathrm{a}}$ & $13.6 \pm 0.18^{\mathrm{ab}}$ & $10.2 \pm 0.26^{\mathrm{b}}$ & $2.1 \pm 0.04^{\mathrm{a}}$ & $2.0 \pm 0.04^{\mathrm{a}}$ \\
\hline $\min -\max$ & $97.8-140.2$ & $59.5-888$ & $12-17$ & $7.0-15.7$ & $1.8-2.9$ & $1.6-2.6$ \\
\hline $\mathrm{CV}, \%$ & 7.4 & 10.6 & 9.4 & 18.1 & 13.2 & 12.3 \\
\hline \multicolumn{7}{|c|}{ grafting C. officinalis on C. mas (G-08) } \\
\hline $\mathrm{M} \pm \mathrm{m}$ & $76.9 \pm 0.78^{c}$ & $45.7 \pm 0.63^{c}$ & $14.0 \pm 0.17^{\mathrm{a}}$ & $7.8 \pm 0.12^{\mathrm{c}}$ & $1.3 \pm 0.02^{\mathrm{cd}}$ & $1.2 \pm 0.02^{\mathrm{ab}}$ \\
\hline $\min -\max$ & $63.7-89.0$ & $39.7-59.4$ & $12-18$ & $6.4-10.1$ & $0.9-1.8$ & $0.9-1.6$ \\
\hline $\mathrm{CV}, \%$ & 7.2 & 9.8 & 8.7 & 10.8 & 13.1 & 14.1 \\
\hline
\end{tabular}

Note: means followed by different letters are different at $P<0.05$. Each value represents the mean of three independent experiments $( \pm S D)$; min - minimum values; max - maximum values; CV, \% - coefficient of variation.

Airport (Zhuliany), Kyiv), 2018 was marked by the optimum of precipitations in May and August and significantly higher monthly rainfalls in June. This indicates that C. officinalis genotypes respond very well to moisture. These indicators are important for the development of agricultural measures for the cultivation of $\mathrm{C}$. officinalis in Ukraine.
There is still very little information on the biometric indices of $C$. officinalis fruits and leaves. This is probably because the introduction and breeding of this species are not widespread so much. The data about the size and weight of the fruit of nine types of germplasm, selected from 73 naturallyoccurring growth specimens in North- 
Western China (collection of the Laboratory of Development of Endangered Chinese Raw Narcotic Resources) were reported (Li et al., 2012). The comparison shows that the limits of variation of the mean fruit size in Chinese and Kyiv genotypes are quite similar. The smallest size of the fruit is practically the same, and the maximum is larger in Chinese genotypes. In particular, the maximum length of the mature fruit in the G-04 was $16.7 \mathrm{~mm}$, and in the two Chinese genotypes - $19.1 \mathrm{~mm}$. The same tendency has been observed for fruit weight. According to the Flora of China (Xiang \& Boufford, 2005), the fruits of C. officinalis wild individuals may reach $12-18 \mathrm{~mm}$ long and 5-6 $\mathrm{mm}$ in diameter. The length of the fruits of investigated genotypes is within the reported range of variability for the wild species. Still, in most cases, it is closer to the upper limit of variation. However, the diameter of the investigated fruits is almost twice higher in comparison with wild species. Consequently, the fruits of the introduced plants, both Chinese and Kyiv, vary more in diameter than in length. The fruits of the cultivar Etude, which we examined, exceeded those of all nine Chinese germplasm types by the size (e.g., length $19.9 \mathrm{~mm}$ vs. $19.1 \mathrm{~mm}$, respectively) and weight (1.8 mg vs. $1.6 \mathrm{mg}$, respectively). This indicates the prospect of further breeding work with 'Etude' in order to produce largefruited forms with long-fading after ripening fruits.

The variability in leaf quantitative traits is resulted from both their plasticity and genotype variation, and thus reflects the relationship between plant and climate (Royer et al., 2008). Our current research has confirmed this statement. We found that the quantitative parameters of leaves of the studied C. officinalis genotypes demonstrate higher variation comparing to the fruits. The biometric indices of the leaves, as well as the fruits, in the studied genotypes were closer (or beyond) to their variation in the wild species reported by Xiang \& Boufford (2005). This fact, again, indicates that the genotypes of C. officinalis introduced into the NBG were sufficiently adapted to the temperate continental climate of the Right-Bank Forest Steppe of Ukraine. The leaves of cultivar Etude were almost indistinguishable from the leaves of C. officinalis genotypes. There was also no significant change in the number of largest lateral veins of the leaf because the wild individuals of C. officinalis and C. mas are quite similar in this respect. The leaves of C. mas are characterized by 6-10 (12) lateral veins (Poyarkova, 1951; Murrell \& Poindexter, 2016), and the leavevs of C. officinalis - by 12-14 veins (Xiang \& Boufford, 2005). Interesting was the nature of inheritance of other morphological features of the leaf blade by cultivar Etude. The shape of the leaf, especially its apex (gradually narrowed) and color (colorless, not brown) of trichomes in the cultivar Etude, are similar to C. mas. However, the number of lateral veins in 'Etude' is closer to the maternal species, C. officinalis. Thus, the cultivar Etude is characterized by the combined inheritance of leaf features.

Hybridization between Cornus taxa is still a poorly investigated phenomenon. Having nearly 60 species (Xiang \& Boufford, 2005; Murrell \& Poindexter, 2016), this genus includes only a few known species producing hybrids. Both in natural conditions and botanical gardens, C. florida, C. kousa, and C. nuttallii from the subgenus Kraniopsis Raf. (Molnar, 2018) can hybridize with each other. Some natural hybrids were also described between C. racemosa Lam. and C. rugosa Lam. (Wagner, 1990). Prospective natural hybrids were also reported between C. mas and C. officinalis (Morozowska et al., 2013) and between C. controversa Hemsl. and C. alternifolia L.f. (Gawrońska et al., 2019). Thus, the data we have obtained about the cultivar Etude is important not only for clarifying the characteristics of industrial use, but also to investigate the peculiarities of hybridization and to characterize the inheritance of traits in the genus Cornus in general.

\section{Conclusions}

The value of biometric parameters of fruits and leaves in the adaptation strategy of C. officinalis plants and its hybrid under the conditions of introduction were evaluated. Important and indifferent signs for breeding work to obtain promising productive varieties for industrial cultivation were determined. Among the cultivated at the NBG, the cultivar Etude and genotypes G-03 and G-04 of C. officinalis were the most noteworthy. Cultivar Etude is promising for large-fruited forms with fruits 
that do not fade long after ripening. The data obtained indicate the strong potential of C. officinalis for commercial use in Ukraine. The results of this study are also important for the investigation of hybridization in the genus Cornus. Biometric characteristics of the fruit, endocarp, and leaf were found determining the degree of adaptation of C. officinalis to the current climate conditions of Ukraine (in particular, the Right-Bank Forest Steppe) and essential for further breeding work.

\section{References}

Atkinson, B. A., Stockey, R. A., \& Rothwell, G. W. (2016). Cretaceous origin of dogwoods: an anatomically preserved Cornus (Cornaceae) fruit from the Campanian of Vancouver Island. PeerJ, 4, e2808. https://doi.org/10.7717/peerj.2808

Brindza, P., Brindza, J., Tóth, D., Klimenko, S. V., \& Grigorieva, O. (2007). Slovakian cornelian cherry (Cornus mas L.): Potential for cultivation. In Proceedings of the XXVII International Horticultural Congress - IHC2006: II International Symposium on Plant Genetic Resources of Horticultural Crops. Acta Horticulturae, 760, 433-437. https://doi. org/10.17660/actahortic.2007.760.59

Call, A., Sun, Y.-X., Yu, Y., Pearman, P. B., Thomas, D. T., Trigiano, R. N., Carbone I., \& Xiang, Q.-Y.J. (2015). Genetic structure and postglacial expansion of Cornus florida L. (Cornaceae): integrative evidence from phylogeography, population demographic history, and species distribution modeling. Journal of Systematics and Evolution, 54(2), 136-151. https://doi. org/10.1111/jse.12171

Cao, B., Bai, C., Zhang, L., Li, G., \& Mao, M. (2016). Modeling habitat distribution of Cornus officinalis with Maxent modeling and fuzzy logics in China. Journal of Plant Ecology, 9(6), 742-751. https://doi. org/10.1093/jpe/rtw009

Ceccarelli, S., Grando, S., Maatougui, M., Michael, M., Slash, M., Haghparast, R., Rahmanian, M., Taheri, A., Al-Yassin A., Benbelkacem, A., Labdi, M., Mimoun, H., \& Nachit, M. (2010). Plant breeding and climate changes. The Journal of Agricultural Science, 148(6), 627-637. https://doi.org/10.1017/ s0021859610000651

Cornescu, F. C., \& Cosmulescu, S. N. (2017). Morphological and biochemical characteristics of fruits of different cornelian cherry (Cornus mas L.) genotypes from spontaneous flora. Notulae Scientia Biologicae, 9(4), 577-581. https:// doi.org/10.15835/nsb9410161
Crossa, J., Pérez-Rodríguez, P., Cuevas, J., Montesinos-López, O., Jarquín, D., de los Campos, G., Burgueño, J., GonzálezCamacho. J. M., Pérez-Elizalde, S., Beyene, Y., Dreisigacker, S. Singh, R., Zhang X., Gowda, M., Roorkiwal, M., Jarquín, D., Rutkoski, J., \& Varshney R. K. (2017). Genomic selection in plant breeding: Methods, models, and perspectives. Trends in Plant Science, 22(11), 961-975. https:// doi.org/10.1016/j.tplants.2017.08.011

Czerwińska, M. E., \& Melzig, M. F. (2018). Cornus mas and Cornus officinalis - coincidences and differences of two medicinal plants traditionally used. Frontiers in Pharmacology, 9(894), 1-28. https://doi.org/10.3389/fphar.2018.00894

Dinda, B., Kyriakopoulos, A. M., Dinda, S., Zoumpourlis, V., Thomaidis, N. S., Velegraki, A., Markopoulos, C., \& Dinda, M. (2016). Cornus mas L. (cornelian cherry), an important European and Asian traditional food and medicine: Ethnomedicine, phytochemistry and pharmacology for its commercial utilization in drug industry. Journal of Ethnopharmacology, 193, 670-690. https://doi.org/10.1016/j. jep.2016.09.042

Eyde, R. H. (1988). Comprehending Cornus: Puzzles and progress in the systematics of the dogwood. The Botanical Review (Lancaster), 54(3), 233-351. https://doi.org/10.1007/bf02868985

Feng, C. M., Xiang, Q. Y., \& Franks, R. G. (2011). Phylogeny-based developmental analyses illuminate evolution of inflorescence architectures in dogwoods (Cornus s.l., Cornaceae). New Phytologist, 191(3), 850$869 . \quad$ https://doi.org/10.1111/j.14698137.2011.03716.x

Ferguson, I. K. (1966). The Cornaceae of the southeastern United States. Journal of the Arnold Arboretum, 47(2), 106-116.

Fileccia, T., Guadagni, M., Hovhera, V., \&Bernoux, M. (2014). Ukraine - Soil fertility to strengthen climate resilience: Preliminary assessment of the potential benefits of conservation agriculture: Main report (English). Washington, DC: World Bank Group. Retrieved from http://documents.worldbank. org/curated/en/755621468319486733/Mainreport

Fodor, S. S. (1974). Flora of Transcarpathia. Kyiv: Vyscha Shkola. (In Ukrainian).

Fu, C. N., Li, H. T., Milne, R., Zhang, T., Ma, P. F., Yang, J., Li, D. Z., \& Gao, L. M. (2017). Comparative analyses of plastid genomes from fourteen Cornales species: inferences for phylogenetic relationships and genome evolution. $B M C$ Genomics, 1(1), 956. https://doi.org/10.1186/ s12864-017-4319-9 
Gawrońska, B., Morozowska, M., Nuc, K., Kosiński, P., \& Słomski, R. (2019). What nature separated, and human joined together: About a spontaneous hybridization between two allopatric dogwood species (Cornus controversa and C. alternifolia). PLOS One, 14(12), e0226985. https://doi.org/10.1371/journal.pone.0226985

Grygorieva, O., Abrahamová, V., Karnatovská, M., Bleha, R., \& Brindza, J. (2014). Morphological characteristic of fruit, drupes and seeds genotypes of Ziziphus jujuba Mill. Potravinarstvo: Slovak Journal of Food Sciences, 8(1), 306-314. https://doi.org/10.5219/414

Grygorieva, O., Klymenko, S., Ilinska, A., \& Brindza, J. (2018a). Variation of fruits morphometric parameters of Elaeagnus multiflora Thunb. germplasm collection. Potravinárstvo: Slovak Journal of Food Sciences, 12(1), 527-532. https://doi.org/10.5219/922

Grygorieva, O., Klymenko, S., Vergun, O., Hudz, N., Nikolaieva, N., Schubertová, Z., Palamarchuk, O., \& Brindza, J. (2017). Morphological characteristics and determination of volatile organic compounds of Diospyros virginiana L. genotypes fruits. Potravinarstvo: Slovak Journal of Food Sciences, 11(1), 612-622. https://doi.org/10.5219/808

Grygorieva, O., Klymenko, S., Vinogradova, Y., Vergun, O., \& Brindza, J. (2018b). Variation in morphometric traits of fruits of Mespilus germanica L. Potravinarstvo: Slovak Journal of Food Sciences, 12(1), 782-788. https://doi. org/10.5219/999

Hammer, Ø., Harper, D. A. T., \& Ryan, P. D. (2001). PAST: Paleontological statistics software package for education and data analysis. Palaeontologia Electronica, 4(1), 01. Retrieved from http://palaeoelectronica.org/2001_1/past/issue1_01.htm

Holubkova, I. M. (2017). Morphological features of Persica species and varieties in the ForestSteppe of Ukraine. Plant Varieties Studying and Protection, 13(1), 64-70. (In Ukrainian). https:// doi.org/10.21498/2518-1017.13.1.2017.97307

Hosseinpour-Jaghdani, F., Shomali, T., GholipourShahraki, S., Rahimi-Madiseh, M., \& RafieianKopaei, M. (2017). Cornus mas: A review on traditional uses and pharmacological properties. Journal of Complementary and Integrative Medicine, 14(3), 20160137. https://doi.org/10.1515/jcim2016-0137

Huang, J., Zhang, Y., Dong, L., Gao, Q., Yin, L., Quan, H., Chen, R., Fu, X., \& Lin, D. (2018). Ethnopharmacology, phytochemistry, and pharmacology of Cornus officinalis Sieb. et Zucc. Journal of Ethnopharmacology, 213, 280-301. https://doi.org/10.1016/j.jep.2017.11.010
Hutchinson, J. (1942). Neglected generic characters in the family Cornaceae. Annals of Botany, 6(21), 83-93. https://doi.org/10.1093/oxfordjournals. aob.a088402

Jaćimović, V., \& Božović, Đ. (2017). Evaluation of cornelian cherry (Cornus mas L.) varieties and selections under the conditions of Gornje Polimlje region. Voćarstvo, 51(199/200), 81-86.

Ji, L. L., Wang, X., Li, J. J., Zhong, X.J., Zhang, B., Juan, J., \& Shang, X. Y. (2019). New iridoid derivatives from the fruits of Cornus officinalis and their neuroprotective activities. Molecules, 24(3), 625. https://doi.org/10.3390/molecules24030625

Kazimierski, M., Regula, J., \& Molska, M. (2019). Cornelian cherry (Cornus mas L.) - characteristics, nutritional and pro-health properties. Acta Scientiarum Polonorum Technologia Alimentaria, 18(1), 5-12. https://doi.org/10.17306/j.afs.0628

Kleopov, Y. D. (1990). Analysis of the flora of the broadleaved forests in the European part of the USSR. Kyiv: Naukova Dumka. (In Russian)

Klimenko, S. (2004). The cornelian cherry (Cornus mas L.): Collection, preservation, and utilization of genetic resources. Journal of Fruit and Ornamental Plant Research, 12, 93-98.

Klymenko, S., \& Klymenko, O. (2017). Leaf anatomy of the members of Cornaceae family in conditions of the Forest-Steppe of Ukraine. Annals of the Romanian Society for Cell Biology, 21(2), 28-39.

Klymenko, S., Grygorieva, O., \& Brindza, J. (2017a). Less known species of fruit crops. Slovak University of Agriculture in Nitra. https://doi. org/10.15414/2017.fe-9788055217659

Klymenko, S., Grygorieva, O., \& Onyshuk, L. (2017b). Biological bases of seed and vegetative reproduction of cornelian cherry (Cornus mas L.) in nature and culture. Agrobiodiversity for Improving Nutrition, Health and Quality, 1, 233248. http://dx.doi.org/10.15414/agrobiodiversi ty.2017.2585-8246.233-248

Klymenko, S., Grygorieva, O., Vasiuk, E., \& Skrypchenko, N. (2017c). Bioecological and morphological features, adaptive selection of species Castanea sativa Mill., Cornus officinalis Sieb. et Zucc., Pseudocydonia sinensis C.K. Schneid., Ziziphus jujuba Mill., Viburnum opulus L., Crataegus spp. In D. B. Rakhmetov (Ed.), Adaptation of introduced plants in Ukraine (pp. 221-311). Kyiv: Phytosotsiocenter. (In Ukrainian)

Klymenko, S., Kucharska, A. Z., Sokół-Łętowska, A., \& Piórecki, N. (2019). Antioxidant activities and phenolic compounds in fruits of cultivars of cornelian cherry (Cornus mas L.). Agrobiodiversity for Improving Nutrition, Health and Life Quality, 3, 484499. Retrieved from https://agrobiodiversity. uniag.sk/scientificpapers/article/view/306 
Krośniak, M., Gąstoł, M., Szałkowski, M., Zagrodzki, P., \& Derwisz, M. (2010). Cornelian cherry (Cornus mas L.) juices as a source of minerals in human diet. Journal of Toxicology and Environmental Health, Part A, 73(17-18), 1155-1158. https://doi.org/10.1080/15287394.2010.491408

Kryvoruchko, O. V., \& Kryvoruchko E. V. (2018). Phenolic compounds of Cornus mas and Cornus officinalis. Ukrainian Biopharmaceutical Journal, 1(54), 42-45. (In Ukrainian). https://doi. org/10.24959/ubphj.18.151

Li, G. S., Zhang, L. J., \& Bai, C. K. (2012). Chinese Cornus officinalis: TGenetic resources, genetic diversity and core collection. Genetic Resources and Crop Evolution, 59(8), 1659-1671. https://doi. org/10.1007/s10722-011-9789-z

Li, X., Ma, Q., Zhou, H., Yang, Y., Li, H., \& Wang J. (2020). Characterization of the complete chloroplast genome of Cornus bretschneideri (Cornaceae). Mitochondrial DNA, Part B, 5(1), 543544. https://doi.org/10.1080/23802359.2019.17 10281

Mamaev, S. A. (1975). The main principles of the methodology for the study of intraspecific variability of woody plants. In Individual and ecological-geographical variability of plants (pp. 3-14). Sverdlovsk: Ural Worker. (In Russian)

Manchester, S. R., Xiang, X. P., \& Xiang, Q. Y. (2010). Fruits of cornelian cherries (Cornaceae: Cornus subg. (Cornus) in the Paleocene and Eocene of the Northern Hemisphere. International Journal of Plant Sciences, 171(8), 882-891. https://doi. org/10.1086/655771

Molnar, T. J. (2018). Breeding powdery mildew resistant dogwoods and more at Rutgers University. International Plant Propagators' Society. Combined Proceedings of Annual Meetings, 68, 385-395.

Monka, A., Grygorieva, O., Chlebo, P., \& Brindza, J. (2014). Morphological and antioxidant characteristics of quince (Cydonia oblonga Mill.) and chinese quince fruit (Pseudocydonia sinensis Schneid.). Potravinarstvo: Slovak Journal of Food Sciences, 8(1), 333-340. https://doi. org/10.5219/415

Moradi, Y., Khadivi, A., \& Salehi-Arjmand, $H$. (2019). Morphological and pomological characterizations of cornelian cherry (Cornus mas L.) to select the superior accessions. Scientia Horticulturae, 249, 208-218. https://doi. org/10.1016/j.scienta.2019.01.039

Morozowska, M., Gawronska, B., \& Woznicka, A. (2013). Morphological, anatomical and genetic differentiation of Cornus mas, Cornus officinalis and their interspecific hybrid. Dendrobiology, 70, 45-57. https://doi.org/10.12657/denbio.070.005
Murrell, Z. E. (1993). Phylogenetic relationships in Cornus (Cornaceae). Systematic Botany, 18(3), 469495. https://doi.org/10.2307/2419420

Murrell, Z. E., \& Poindexter, D. B. (2016). Cornaceae Berchtold \& J. Presl. In Flora of North America Editorial Committee (Eds.) Flora of North America North of Mexico, Vol. 12: Magnoliophyta: Vitaceae to Garryaceae. New York and Oxford. Retrieved from http:// www.efloras.org/florataxon.aspx?flora $i d=1$ \&taxon_id=10219

Ortiz, R. (2018). Role of plant breeding to sustain food security under climate change. In S. S. Yadav, R. J. Redden, J. L. Hatfield, A. W. Ebert, \& D. Hunter (Eds.), Food Security and Climate Change (pp. 145-158). John Wiley \& Sons Ltd. https://doi.org/10.1002/9781119180661. ch8

Poyarkova, A. I. (1950). To the question of systematic relations within the Linnaeus genus Cornus L. In B. K. Schischkin (Ed.), Botanical materials of the Herbarium of V.L. Komarov Botanical Institute of the AS USSR, XII (pp. 164-180). Moscow \& Leningrad: Publishing House of the AS of USSR. (In Russian)

Poyarkova, A. I. (1951). Cornaceae Link. In: B. K. Schischkin (Ed.), Flora of the USSR, Vol. 17 (pp. 315-348). Moscow \& Leningrad: Publishing House of the AS USSR. (In Russian)

Prevéy, J. S. (2020). Climate change: Flowering time may be shifting in surprising ways. Current Biology, 30(3), 112-114. https://doi.org/10.1016/j. cub.2019.12.009

Rakhmetov, D. (2018). Non-traditional plant species for bioenergetics. Nitra: Slovak University of Agriculture in Nitra. https://doi. org/10.15414/2018.fe-9788055218557

Reed, S. M. (2004). Self-incompatibility in Cornus florida. Hortscience, 39(2), 335-338. https://doi. org/10.21273/HORTSCI.39.2.335

Royer, D. L., McElwain, J. C., Adams, J. M., \& Wilf, P. (2008). Sensitivity of leaf size and shape to climate within Acer rubrum and Quercus kelloggii. New Phytologist, 179(3), 808-817. https://doi.org/10.1111/j.14698137.2008.02496.x

Schneider, S. H. (2004). Abrupt non-linear climate change, irreversibility and surprise. Global Environmental Change, 14(3), 245-258. https://doi. org/10.1016/j.gloenvcha.2004.04.008

Shindell, D. (2007). Estimating the potential for twenty-first century sudden climate change. Philosophical Transactions of the Royal Society A: Mathematical, Physical and Engineering Sciences, 365(1860), 2675-2694. https://doi.org/10.1098/ rsta.2007.2088 
Stockey, R. A., Nishida, H., \& Atkinson, B. A. (2016). Anatomically preserved fossil cornalean fruits from the Upper Cretaceous of Hokkaido: Eydeia hokkaidoensis gen. et sp. nov. American Journal of Botany, 103(9), 1642-1656. https://doi. org/10.3732/ajb.1600151

Szot, I., Lipa, T., \& Sosnowska, B. (2019). Evaluation of yield and fruit quality of several ecotypes of cornelian cherry (Cornus mas L.) in polish condiotions. Acta Scientiarum Polonorum Hortorum Cultus, 18(6), 139148. https://doi.org/10.24326/asphc.2019.6.14

Takhtajan, A. L. (1987). The system of magnoliophytes. Moscow: Nauka. (In Russian)

Taunk, J., Rani, A., Singh, R., Yadav, N. R., \& Yadav, R. C. (2019). Genomic strategies for improving abiotic stress tolerance in crop plants. In V. Rajpal, D. Sehgal, A. Kumar, S. Raina (Eds.), Genetic enhancement of crops for tolerance to abiotic stress: Mechanisms and approaches. Vol. I (pp. 205-230). Springer. https://doi. org/10.1007/978-3-319-91956-0_9

Wagner, W. H. (1990). A natural hybrid of gray dogwood, Cornus racemosa, and round-leaved dogwood, C. rugosa, from Michigan. The Michigan Botanist, 29(4), 131-137.

Wangerin, W. (1910). Cornaceae. In: A. Engler (Ed.), Das Pflanzenreich, Ser. IV, Fam. 229 (Heft 41). Leipzig: W. Engelmann.

Weaver, R. E. (1976). The cornelian cherries. Arnoldia, 36(2), 50-56.

Woźnicka, A., Melosik, I., \& Morozowska, M. (2015). Quantitative and qualitative differences in morphological traits of endocarps revealed between Cornus L. species. Plant Systematics and Evolution, 301(1), 291-308. https://doi. org/10.1007/s00606-014-1073-1
Xiang, J. Q.-Y., \& Boufford, D. E. (2005). Cornaceae. In Z. Y. Wu, \& P. H. Raven (Eds.), Flora of China, Vol. 14 (Apiaceae through Ericaceae) (pp. 206-221). Beijing: Science Press and St. Louis: Missouri Botanical Garden Press.

Xiang, Q. Y. J., Thomas, D. T., Zhang, W., Manchester, S. R., \& Murrell, Z. (2006). Species level phylogeny of the genus Cornus (Cornaceae) based on molecular and morphological evidence - implications for taxonomy and Tertiary intercontinental migration. Taxon, 55(1), 9-30. https://doi. org/10.2307/25065525

Yu, Y., Xiang, Q. Y., Manos, P. S., Soltis, D. E., Soltis, P. S., Song, B. H., Cheng, S. F., Liu, X., \& Wong, G. (2017). Whole-genome duplication and molecular evolution in Cornus L. (Cornaceae) - insights from transcriptome sequences. PLOS One, 12, e0171361. https://doi.org/10.1371/ journal.pone.0171361

Yue, X., Li, X., Chen, X., Ashraf, M. A., Liu, Z., Bi, H., Zheng, D., Zhao, Y., \& Peng, W. (2018). Molecules and functions of Cornus officinalis bark volatiles. Emirates Journal of Food \& Agriculture, 30(10), 828-838. https://doi.org/10.9755/ejfa.2018.v30. i10.1826

Zhang,J., Franks, R. G., Liu, X., Kang, M., Keebler, J. E., Schaff, J. E., Huang, H. W., \& Xiang, Q. Y. J. (2013). De novo sequencing, characterization, and comparison of inflorescence transcriptomes of Cornus canadensis and C. florida (Cornaceae). PLOS One, 8, e82674. https://doi.org/10.1371/ journal.pone.0082674

\section{Біометрична характеристика листків і плодів генотипів Cornus officinalis Siebold et Zucc. в Національному ботанічному саду ім. М.М. Гришка НАН України}

С.В. Клименко *, А.П. Ільїнська **

Національний ботанічний сад імені М.М. Гришка НАН України, вул. Тімірязєвська, 1, м. Київ, 01014, Україна; * cornusklymenko@gmail.com, ** ilynska@ukr.net

У контексті глобальних змін клімату сучасна стратегія агроекономіки передбачає інтродукцію нетрадиційних видів рослин і селекцію нових економічно перспективних сортів, пристосованих до різкої зміни погодних умов. Китайський за походженням Cornus officinalis (Cornaceae) $є$ новим у такому аспекті для України; його реінтродукцію розпочато у Національному ботанічному саду імені М.М. Гришка НАН України в 1993 р.

Мета цього дослідження - визначити біометричні параметри плодів та листків генотипів C. officinalis, гібриду C. officinalis × C. mas (сорт Етюд) та генотипу одержаного від щеплення C. officinalis на C. mas 
за умов культивування в Національному ботанічному саду імені М.М. Гришка НАН України, для з'ясування ступеня адаптованості виду до сучасного клімату України (зокрема, Правобережного Лісостепу) і відбору перспективних генотипів для селекційної роботи.

Матеріали і методи. У дослідженні було використано 26-річну материнську рослину, отриману дворічним саджанцем у 1993 році з розплідника "Northwoods Wholesale Nursery" (м. Молалла, Орегон, США), де рослини цього виду вирощували як декоративні; сорт Етюд - гібрид від схрещування C. officinalis × C. mas; генотип від щеплення C. officinalis на C. mas. У нашому дослідженні материнську рослину позначено як G-01, а решту генотипів як G-02-G-08. Для цих рослин було вивчено біометричні параметри плоду (довжина, діаметр і маса), ендокарпу (довжина, діаметр і маса), квітконіжки (довжина і товщина), пластинки листка (довжина, ширина і кількість бічних жилок) і черешка (довжина, ширина і товщина). Також було досліджено динаміку формування плоду та ендокарпу протягом сезону (генотипи G-01-G-03 i G-05) та порівняно біометричні характеристики плодів генотипів G-01-G-05 урожаю за два роки, 2010 та 2018. Ці роки було обрано, оскільки вони вирізнялися дуже сприятливими для плодових рослин погодними умовами. Кількісні результати було опрацьовано методами варіаційної статистики, з використанням безкоштовного програмного забезпечення для наукового аналізу даних PAST 2.10. Мінливість показників було визначено за допомогою коефіцієнта варіації. Різницю між зразками оцінено за допомогою тесту Тукі-Крамера, а рівень мінливості - відповідно до класифікації Мамаєва (1975).

Результати. Було визначено біометричні параметри плода: довжина 13,8-19,9 мм, діаметр 7,711,2 мм, маса 600-1800 мг; ендокарпу: довжина 12,1-13,8 мм, діаметр 4,5-5,4 мм, маса 200-300 мг; квітконіжка: довжина 9,0-14,0 мм, товщина 0,2-0,6 мм; листової пластинки: довжина 73,5-117,1 мм, ширина 73,5-75,2 мм, кількість бічних жилок 12,9-14,3; черешка: довжина 9,4-11,4 мм, ширина 1,3-2,1 мм, товщина 1,1-2,0 мм. У 2010 році найбільші плоди мав генотип G-01, а найменші - G-03. Коефіцієнт варіювання лінійних параметрів плода та ендокарпу становив 5,7-10,1%, що відповідає дуже низькому або низькому рівню мінливості. Варіювання маси плодів та ендокарпа було більшим; діапазон коефіцієнта варіювання від 7,0 до 28,3 \%. Амплітуда лінійних параметрів листка широка. Найбільші листки мали генотипи G-08 та G-01, найменші - генотип G-02. Сорт Етюд відрізнявся від генотипів C. officinalis розміром та масою плодів врожаю 2018 року ( $\mathrm{M}=1800$ мг, max $=2400$ мг) та значно ширшою амплітудою варіювання їхньої довжини (17,9-22,6 проти 14,3-18,2 мм). Сорт Етюд за середніми морфометричними показниками листка та за кількістю жилок, у цілому, не відрізнявся від досліджених генотипів C. officinalis, але ширина листкової пластинки була значно більшою і становила 51,5 мм проти 35,4 мм (G-01) і 43,1 мм (G-07).

Висновки. Отримані дані важливі для комерційного використання C. officinalis та сорту Етюд як харчових і лікарських рослин, а також для подальшої селекції сортів в погодно-кліматичних умовах України і аналізу особливостей гібридизації у роді Cornus. 